\title{
Relationships between frontal structures and zooplankton communities along a cross-shelf transect in the Bay of Biscay (1995 to 2003)
}

\author{
Aitor Albaina*, Xabier Irigoien \\ Marine Research Division, AZTI Foundation, Herrera Kaia Portualde, z/g 20110, Pasaia (Gipuzkoa), Spain
}

\begin{abstract}
A high-resolution cross-shelf transect in front of the mouth of the Gironde estuary $\left(45.62^{\circ} \mathrm{N}\right.$, and from 1.36 to $4.27^{\circ} \mathrm{W}$, with 3 nautical miles between stations) is carried out once a year during the spring stratification period. In this study, we analysed the zooplankton samples in 1995, 1997, 1999, 2001 and 2003 in order to elucidate the effects that mesoscale structures exert over the zooplankton community. The Gironde river plume and a shelf-break front due to internal wave generation over the slope are the main frontal structures described along the transect. Their position and magnitude determine zooplankton community changes both qualitatively and quantitatively. Two peaks of zooplankton abundance and distinct zooplankton assemblages were found to be related to the river plume and the frontal structure associated with the shelf-break. However, the distribution of biomass was more homogenous, suggesting that other factors apart from enhancement of primary production related to the location of frontal structures are involved in the determination of the pattern of secondary production along the transect.
\end{abstract}

KEY WORDS: Fronts · Zooplankton · Mesoscale structures · Bay of Biscay $\cdot$ Internal waves $\cdot$ Gironde river plume $\cdot$ Shelf-break

\section{INTRODUCTION}

Oceanographic fronts are regions of larger-thanaverage horizontal gradients of water properties such as temperature, salinity, density, turbidity, or colour (Joyce 1983); 'high biological productivity' is often quoted as a significant property of fronts although the cause of this (in situ promoted growth or other mechanisms like passive accumulation) remains under discussion (Le Fevre 1986, Franks 1992a,b). Huge attention is being devoted in marine biology to the study of the relationships between fronts and plankton (e.g. Le Fevre 1986) because of the well-known enhanced biological production and clear community changes encountered in their vicinities (e.g. Fernandez et al. 1993, Pinca \& Dallot 1995, Errhif et al. 1997, Pinca \& Dallot 1997, Pakhomov et al. 2000, Chiba et al. 2001, Labat et al. 2002, Munk et al. 2003).
In contrast with other European shelf areas, such as the North Sea and the Baltic, the zooplankton community in the Bay of Biscay is relatively unknown. Thiriot (1976) reported that the Bay of Biscay was a zone of transition and mixing where up to 300 species could be found. Apart from this and other large-scale descriptive articles (Farran 1926, Beaudouin 1971, Beaudouin 1975, d'Élbee \& Castel 1991), the majority of the research on the Bay of Biscay zooplankton refers to the neritic community. Zooplankton in the wide shelf of the French part of the Bay of Biscay has hardly been investigated, and almost nothing is known about the effect of the frontal structures on the zooplankton community over the shelf area.

The objective of this study was to describe the effects that are exerted over the zooplankton community by the 2 permanent mesoscale structures in the shelf area of the Bay of Biscay: the highly productive Gironde river plume and the shelf-break front. 


\section{MATERIALS AND METHODS}

The Bay of Biscay is part of the sub-temperate eastern North Atlantic and is surrounded by the FrenchSpanish coast (Fig. 1a). Topography, hydrological characteristics, origin and variations of water masses in the bay are reviewed in Koutsikopoulous \& Le Cann (1996).

A cross-shelf transect in front of the mouth of the Gironde estuary $\left(45.62^{\circ} \mathrm{N}, 1.36\right.$ to $4.27^{\circ} \mathrm{W}$ ) (Fig. 1a) is sampled annually in May in the frame of routine anchovy egg abundance and distribution surveys. The 1995, 1997, 1999, 2001 and 2003 transects were selected to analyze the zooplankton abundance and taxonomic composition. Samples were collected every 3 nautical miles (n miles) using vertical hauls of a $150 \mu \mathrm{m}$ PAIROVET net fitted with a flowmeter and lowered to a maximum depth of either 100 or $5 \mathrm{~m}$ above the bottom in shallower stations. The PAIROVET net consists of a paired net with a mouth aperture of $0.05 \mathrm{~m}^{2}$ that is a version of the CalVET net (Smith et al. 1985). The nets are also fitted with a temperature measuring system (minilog or conductivity, temperature, depth profiler [CTD] depending on the cruises) to get the thermal profile of the sampled water mass. Net samples were preserved immediately after collection with $4 \%$ borax buffered formaldehyde. In 2003, a continuous vertical profile of chlorophyll a (chl a) was obtained using a
$\mathrm{Nv}$-shuttle undulating system (Chelsea Instruments) in a transect south of the main one $\left(45.5^{\circ} \mathrm{N}\right.$; Fig. 1). Gironde river daily flow was obtained from the harbour authority of Bordeaux, France. Accumulated flow values for the $15 \mathrm{~d}$ prior to the sampling date were calculated to represent the magnitude of the river outflow.

The qualitative and quantitative analysis of zooplankton was carried out under a stereoscopic microscope and identification was made to species or genus level in the majority of the holoplanktonic groups, and to general categories in meroplanktonic forms. In each sample, a minimum of 200 individuals (all categories included) were counted. Copepod biomass (mg C dry weight $\mathrm{m}^{-3}$ ) was estimated by multiplying the measured densities by conversion factors obtained from the literature; for the dominant copepod species we used species-specific dry weight values for the Bay of Biscay (Sautour \& Castel 1993), and for the remaining species, based on total length measurements for a limited number of individuals, a copepod total length-dry weight regression was used (Gaudy \& Boucher 1983). In both cases we assumed $40 \%$ of carbon content in total dry weight (Bamstedt 1986). Simpson's diversity index (S) (Simpson 1949) and percent similarity index (PSI; e.g. Whittaker \& Fairbanks 1958, Rebstock 2001) were calculated only for the copepod community because of the better taxonomic precision. a)

b)
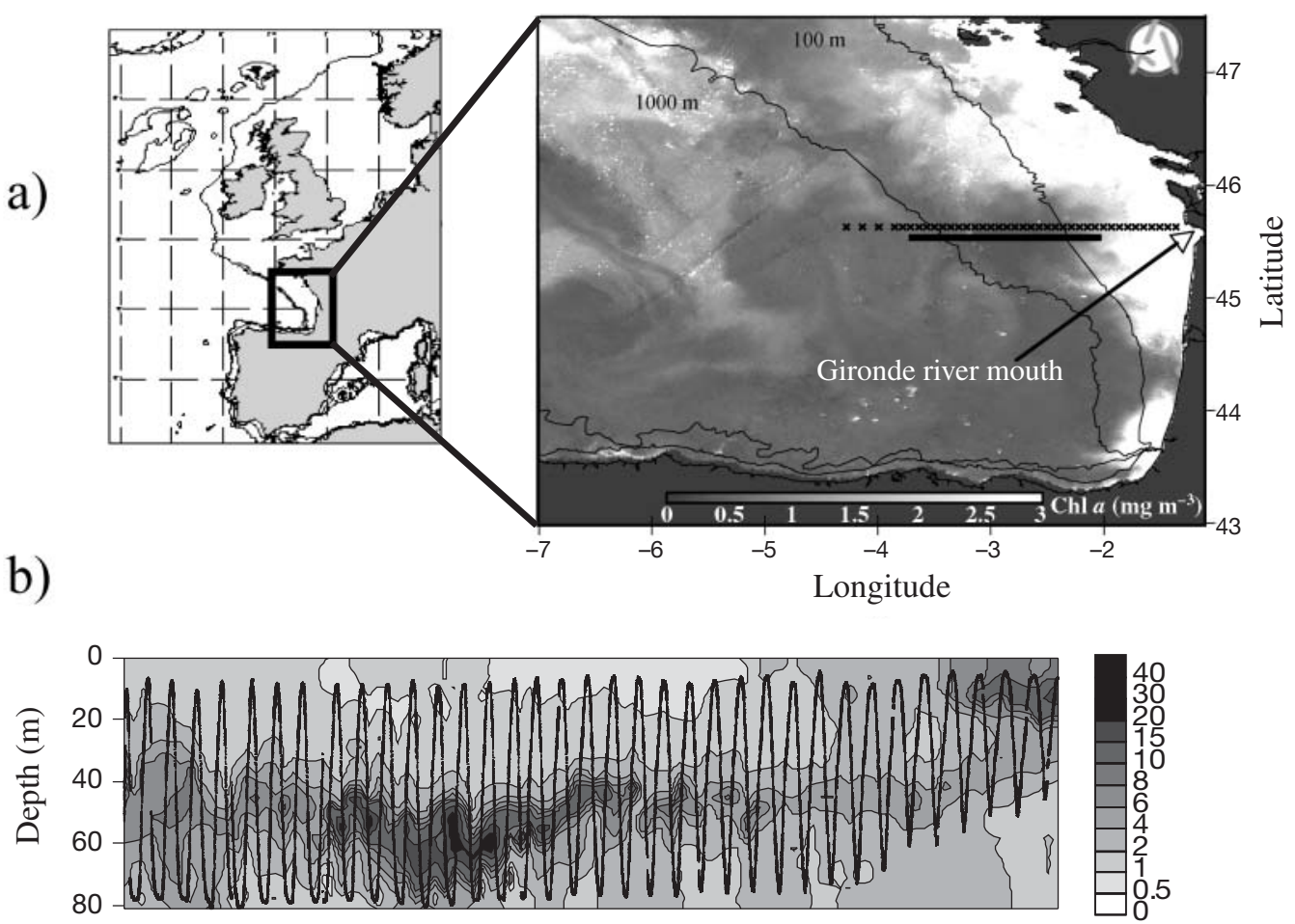

$3.42^{\circ} \mathrm{W}$
Longitude
Fig. 1. (a) Location of the PAIROVET stations (x) and $2003 \mathrm{Nv}$-shuttle transect (solid line) plotted over the chl a satellite image (SeaWiFS satellite) of 2003 survey; 100 and $1000 \mathrm{~m}$ isobaths are shown along with the position of the Gironde river mouth, shelf-break location closely corresponds to the $1000 \mathrm{~m}$ isobath. (b) $2003 \mathrm{Nv}$-shuttle profile of chl a (relative units) 
Multivariate analyses of the sampled stations and the relevant zooplankton taxa were carried out using the Squared Euclidean Ward's Method Cluster (Ward 1963, Pielou 1984) applied to transformed density values: arc-sine (species density/total zooplankton density) was used for the stations dendrogram and $\log _{10}$ (zooplankton species density +1 ) for the analysis of the taxa, using all the zooplankton taxa in the former and only those that conform more than $0.1 \%$ of the zooplankton community in the latter analysis.

Sampling resolution required to discriminate the effects of mesoscale structures on zooplankton communities was tested. Total zooplankton abundance distributions were obtained with decreasing sampling resolution $(6,9,12,15,18,21$ and $24 \mathrm{n}$ miles) by linearly interpolating the values of non-sampled stations with the closest sampled ones. The resulting distributions with a mixture of real and predicted abundance values (observed distributions) were then statistically compared (chi-square) against the lowest sampling resolution, $3 \mathrm{n}$ miles (expected distributions).

\section{RESULTS}

\section{Environmental variables}

The transect sampled crosses the shelf (90 $\mathrm{n}$ miles) in front of the mouth of the Gironde estuary; the depth profile (up to the $200 \mathrm{~m}$ isobath; Fig. 2f) shows 2 distinct zones of the shelf based on the slope inclination: an inner shelf of nearly $45 \mathrm{n}$ miles with a marked slope reaching the $100 \mathrm{~m}$ isobath, and an outer shelf up to the shelf-break with a reduced slope and a depth of 120 to $130 \mathrm{~m}$. The shelf-break is $90 \mathrm{n}$ miles away from the coastline $\left(3.42^{\circ} \mathrm{W}\right)$, and due to the extremely steep slope, depth reaches the $3000 \mathrm{~m}$ isobath within only a further $35 \mathrm{n}$ miles.

Vertical temperature profiles (Fig. 2a-e) showed 2 main features: the progress of the spring stratification period and the location of a clear shelf-break front over the slope. The degree of stratification was related to the mean surface temperature: the coldest years $\left(1995=14.75^{\circ} \mathrm{C}\right.$ and $1997=14.74^{\circ} \mathrm{C}$ ) were also the less stratified ones when compared to 1999 , 2001 and 2003 (with 18, 17.8 and $18.3^{\circ} \mathrm{C}$, respectively). The shelf-break front was found on all of the cruises (Fig. 2a-e). Two main peaks of chl $a$ are found along the transect (Fig. 1): a surface peak located in the plume-influenced zone and a deep one (40 to $60 \mathrm{~m}$ ) starting just before the shelf-break and extending to the outer shelf.

\section{Zooplankton community}

Taxonomic categories along with median, maximum, minimum and average percentage are shown in Table 1. A total of 63 taxa were identified; among them, 16 taxa (11 being copepods) had mean percentage values that exceeded $1 \%$. Copepods represent nearly $86 \%$ of all the zooplankton and 3 copepod categories (27\% Oithona similis , $17 \%$ P-Calanus [category
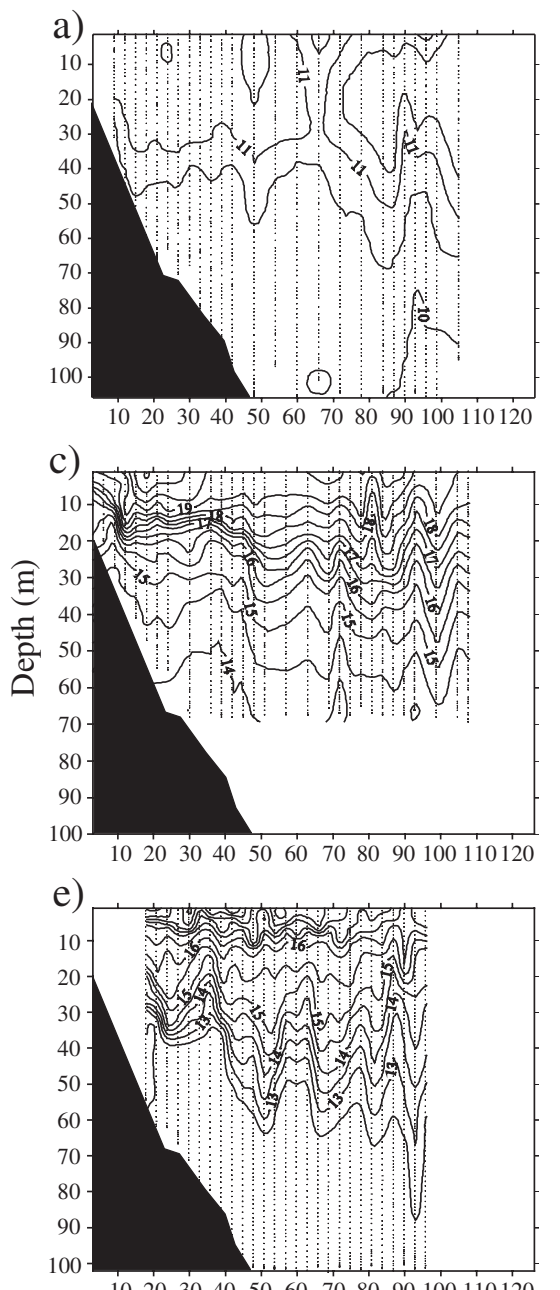

Distance from coast ( $\mathrm{n}$ miles)

Fig. 2. Vertical profiles of temperature $\left({ }^{\circ} \mathrm{C}\right)$ for the Gironde transect: (a) 1995 (19 May); (b) 1997 (21 May); (c) 1999 (1 June); (d) 2001 (28 May); and (e) 2003 (31 May). Bottom profile and sampled depths are shown in all panels. Note that not all the stations were sampled every year. Depth profile up till $200 \mathrm{~m}$ is displayed in (f) 
Table 1. Taxonomic list with mean, maximum and minimum values for density (ind. $\mathrm{m}^{-3}$ ), mean values for contribution (\%) to total abundance of each taxon and estimated biomass values for the copepod community $\left(\mu \mathrm{g} \mathrm{C} \mathrm{m}^{-3}\right)$. Code: codes used in species cluster

\begin{tabular}{|c|c|c|c|c|c|}
\hline Taxon & Code & Mean (ind. $\mathrm{m}^{-3}$ ) & Maximum (ind. $\mathrm{m}^{-3}$ ) & Minimum (ind. $\mathrm{m}^{-3}$ ) & Mean $\%$ \\
\hline Jellyfishes except $S$. Bitentaculata & JELLY & 56.72 & 632.91 & 0.00 & 1.04 \\
\hline Solmundella bitentaculata & SOLMU & 16.15 & 121.07 & 0.00 & 0.46 \\
\hline Siphonophora & SIPHO & 122.74 & 631.76 & 0.00 & 2.82 \\
\hline Beroe spp. (Ctenophora) & & 1.09 & 158.23 & 0.00 & 0.01 \\
\hline Gastropod veliger & GAVEL & 35.88 & 2373.40 & 0.00 & 0.55 \\
\hline Bivalve veliger & BIVEL & 38.43 & 1380.43 & 0.00 & 0.54 \\
\hline Tomopteris spp. & & 0.34 & 18.13 & 0.00 & 0.01 \\
\hline Polychaeta except Tomopteris & POLYC & 24.12 & 949.36 & 0.00 & 0.45 \\
\hline Podon spp. & PODON & 7.24 & 108.92 & 0.00 & 0.15 \\
\hline Evadne nordmanni & EVNOR & 78.11 & 1045.67 & 0.00 & 2.11 \\
\hline Evadne spinifera & EVSPI & 9.00 & 231.57 & 0.00 & 0.27 \\
\hline Bryozoa (Cyphonautes larvae) & & 4.87 & 316.45 & 0.00 & 0.06 \\
\hline Ostracoda & & 0.73 & 25.77 & 0.00 & 0.02 \\
\hline Calanoides carinatus & CCARI & 7.22 & 140.66 & 0.00 & 0.27 \\
\hline Calanus helgolandicus & CHELG & 96.54 & 867.37 & 0.00 & 1.19 \\
\hline Mesocalanus tenuicornis & MESTE & 3.74 & 45.23 & 0.00 & 0.15 \\
\hline Neocalanus gracilis & & 0.05 & 8.23 & 0.00 & 0.00 \\
\hline Neocalanus robustior & & 0.31 & 25.77 & 0.00 & 0.01 \\
\hline Eucalanus spp. & & 3.00 & 49.62 & 0.00 & 0.08 \\
\hline Calocalanus spp. & CALOC & 11.27 & 131.39 & 0.00 & 0.37 \\
\hline Ischnocalanus spp. & & 2.68 & 46.88 & 0.00 & 0.06 \\
\hline P-Calanus (Parac./Claus./Pseud./Cteno. copepodids) & P-CAL & 766.28 & 4526.30 & 113.78 & 17.23 \\
\hline Paracalanus parvus & PARAC & 117.99 & 1107.59 & 0.00 & 2.99 \\
\hline Clausocalanus spp. & CLAUS & 95.07 & 605.07 & 0.00 & 2.69 \\
\hline Pseudocalanus elongatus & PSEUD & 33.52 & 405.91 & 0.00 & 0.63 \\
\hline Ctenocalanus vanus & CTENO & 44.01 & 147.97 & 0.00 & 1.29 \\
\hline Temora longicornis & TEMLO & 162.10 & 1424.04 & 0.00 & 2.76 \\
\hline Temora stylifera & & 0.53 & 33.64 & 0.00 & 0.01 \\
\hline Centropages spp. & CENTR & 139.00 & 836.66 & 0.00 & 3.13 \\
\hline Isias clavipes & & 0.08 & 12.80 & 0.00 & 0.00 \\
\hline Candacia spp. & CANDA & 4.10 & 73.47 & 0.00 & 0.14 \\
\hline Bradyidius armatus & & 0.09 & 13.50 & 0.00 & 0.00 \\
\hline Metridia spp. + Pleuromamma spp. & ME-PL & 8.93 & 105.78 & 0.00 & 0.26 \\
\hline Euchaeta spp. & EUCHA & 5.14 & 88.34 & 0.00 & 0.17 \\
\hline Aetidius spp. & & 0.74 & 19.85 & 0.00 & 0.03 \\
\hline Diaxis spp. & DIAXI & 7.94 & 149.01 & 0.00 & 0.17 \\
\hline Acartia clausi & ACCLA & 151.19 & 2689.85 & 0.00 & 2.36 \\
\hline Oithona similis & OITSI & 1169.91 & 4803.43 & 73.53 & 27.36 \\
\hline Oithona nana & OITNA & 28.15 & 476.45 & 0.00 & 0.55 \\
\hline Oithona plumifera & OITPL & 60.64 & 344.03 & 0.00 & 1.86 \\
\hline Corycaeus spp. & CORYC & 62.96 & 515.66 & 0.00 & 1.27 \\
\hline Oncaea spp. & ONCAE & 655.85 & 4446.89 & 0.00 & 12.27 \\
\hline Euterpina acutifrons & EUTER & 91.17 & 11234.08 & 0.00 & 0.43 \\
\hline Microsetella spp. & MICRO & 17.51 & 155.94 & 0.00 & 0.55 \\
\hline Clytemnestra spp. & & 2.81 & 69.74 & 0.00 & 0.07 \\
\hline Copepoda nauplius & COPNA & 218.75 & 1740.49 & 0.00 & 4.19 \\
\hline Cirripedia nauplius & CIRNA & 9.65 & 348.56 & 0.00 & 0.14 \\
\hline Cirripedia cypris & & 6.30 & 184.07 & 0.00 & 0.08 \\
\hline Amphipoda & & 1.47 & 32.22 & 0.00 & 0.04 \\
\hline Isopoda & & 1.63 & 41.17 & 0.00 & 0.03 \\
\hline Decapod larvae & DECAP & 7.85 & 79.41 & 0.00 & 0.19 \\
\hline Euphausiacea & EUPHA & 7.39 & 101.76 & 0.00 & 0.28 \\
\hline Mysidacea & & 1.19 & 40.63 & 0.00 & 0.03 \\
\hline Sagitta spp. & SAGIT & 12.81 & 158.82 & 0.00 & 0.30 \\
\hline Echinodermata larvae & ECHIN & 166.18 & 10417.09 & 0.00 & 1.23 \\
\hline Fritillaria spp. & FRITI & 25.56 & 981.43 & 0.00 & 0.87 \\
\hline Oikopleura spp. & OIKOP & 142.26 & 5537.93 & 0.00 & 2.15 \\
\hline Appendicularia & & 4.21 & 90.43 & 0.00 & 0.11 \\
\hline Doliolum spp. & & 2.96 & 63.69 & 0.00 & 0.08 \\
\hline Tornaria larvae & & 0.65 & 30.40 & 0.00 & 0.02 \\
\hline Cephalochordata (Branchiostoma lanceolatum) & & 0.64 & 57.87 & 0.00 & 0.01 \\
\hline Copepoda total & & 3969.28 & 26898.50 & 851.76 & 85.94 \\
\hline Copepoda $0-1 \mathrm{~mm}$ & & 3198.70 & 24366.87 & 629.37 & 78.95 \\
\hline Copepoda $1-2 \mathrm{~mm}$ & & 724.86 & 2669.04 & 108.78 & 19.40 \\
\hline Copepoda $>2 \mathrm{~mm}$ & & 48.67 & 306.89 & 0.00 & 1.75 \\
\hline Zooplankton total & & 4755.44 & 38449.03 & 853.88 & 100.00 \\
\hline \multicolumn{6}{|l|}{ Carbon biomass } \\
\hline Copepoda total & & 10247.09 & 31995.35 & 1741.85 & 100.00 \\
\hline Copepoda $0-1 \mathrm{~mm}$ & & 2765.76 & 20176.69 & 598.65 & 29.96 \\
\hline Copepoda 1-2 mm & & 4350.01 & 18664.96 & 400.82 & 42.66 \\
\hline Copepoda $>2 \mathrm{~mm}$ & & 3131.32 & 28556.20 & 0.00 & 27.38 \\
\hline
\end{tabular}


includes the copepodid stages of the genera Paracalanus, Clausocalanus, Pseudocalanus and Ctenocalanus] and $12 \%$ Oncaea spp.) form the bulk of the zooplankton abundance. We distinguished 3 size categories ( 0 to 1,1 to 2 and $>2 \mathrm{~mm}$ ), representing 78.9 , 19.4 and $1.75 \%$ of the abundance and $30,42.6$ and $27.4 \%$ of the biomass, respectively.

Zooplankton abundance shows a bimodal distribution pattern along the depth gradient, with the main peak in the neritic zone followed by a zone of lower densities in the mid-shelf, a secondary peak over the shelf-break and low abundances in the oceanic-deep water zone (Fig. 3a). In 1999, as an exceptional feature, the principal neritic peak of zooplankton density was restricted to 2 stations.

As a result of the distribution of the different size classes (Fig. 3c-e), the spatial distribution of the copepod community biomass (Fig. 4) differs from that of abundance (Fig. 3b). The biomass of small and medium-sized copepods ( 0 to 1 and 1 to $2 \mathrm{~mm}$ ) presents a bimodal peak with maxima in the neritic waters and the shelf-break, whereas the biomass of large copepods $(>2 \mathrm{~mm})$ peaks at the mid-shelf and over the shelf-break, resulting in a more homogenous longitudinal distribution of the total biomass than that of abundance.

a)

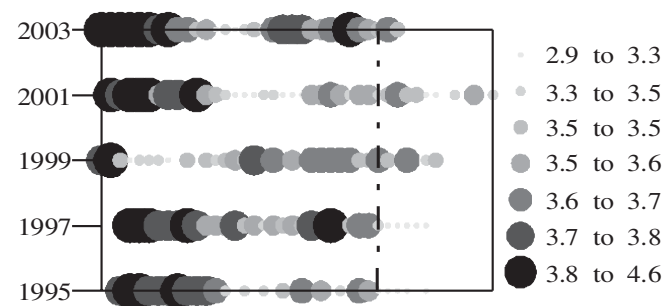

c)

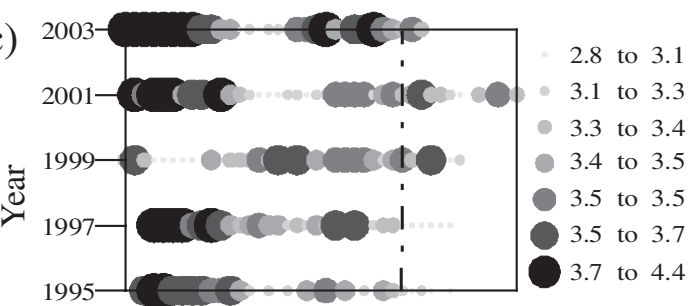

e)

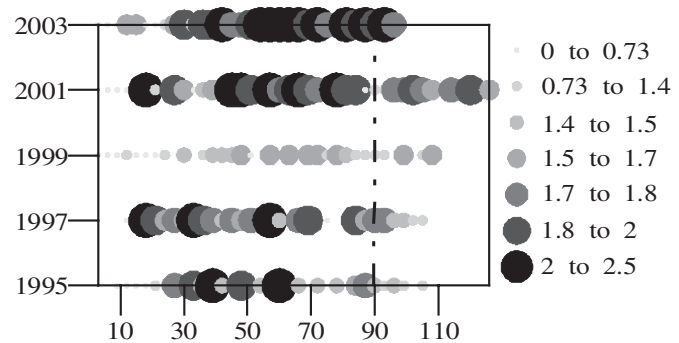

Distance from coast ( $\mathrm{n}$ miles)
$S$ values for the copepod community are presented in Fig. 5; 2 zones with the highest variability in $S$ values, corresponding to stations in the vicinities of the plume and shelf-break, can be distinguished. Low diversity values are found at the shallower stations and in the mid-shelf while the highest diversity values correspond to oceanic stations. The PSI between different years (Fig. 6) shows high similarity values and no noticeable differences except for a very small dissimilarity found in the 1997 to 2003 pair; linear regressions of PSI values within stations in each transect against the distance between stations show high similarity of nearby stations and a smooth but continuous increase in dissimilarity with distance (slopes and intercepts of the regressions are shown in Fig. 7).

Two distinctive groups of stations are identified as a function of the zooplankton composition using the Squared Euclidean Ward's Method Cluster (Fig. 8); both groups (ST-A and ST-B) are further divided into 2 subgroups (ST-A1, ST-A2 and ST-B1, ST-B2). Looking at the spatial distribution of the stations comprised in each cluster (Fig. 9) an obvious depth-based gradient is manifested. Group ST-A1 includes the shallowest stations (always below $100 \mathrm{~m}$ depth or less than $42 \mathrm{n}$ miles from coast) where the river influence is higher. Group ST-A2 includes the stations in the shelf adjacent those

b)

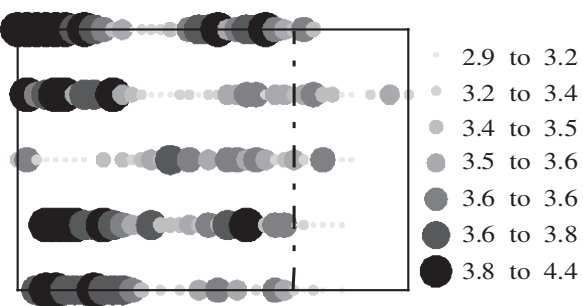

d)

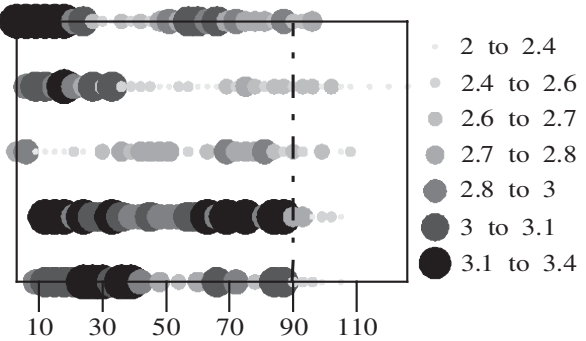

Distance from coast ( $\mathrm{n}$ miles)

Fig. 3. Spatial distributions of the abundance of selected group (ind. $\mathrm{m}^{-3}$; logarithmic scale): (a) total zooplankton; (b) total copepods; (c) 0 to $1 \mathrm{~mm}$ size category copepods; (d) 1 to $2 \mathrm{~mm}$ copepods; and (e) $>2 \mathrm{~mm}$ copepods. Location of the shelf-break ( $90 \mathrm{n}$ miles from the coast) is shown by a vertical dot-dashed line 
of Group ST-A1 up to a mid-shelf depth (approx. $125 \mathrm{~m}$, $70 \mathrm{n}$ miles from the coast). Group ST-B1 includes stations that, despite having locations well below $100 \mathrm{~m}$, dominate the mid- and outer-shelf regions, even crossing the shelf-break, whereas stations at Group ST-B2 are constituted of real oceanic samples (beyond the

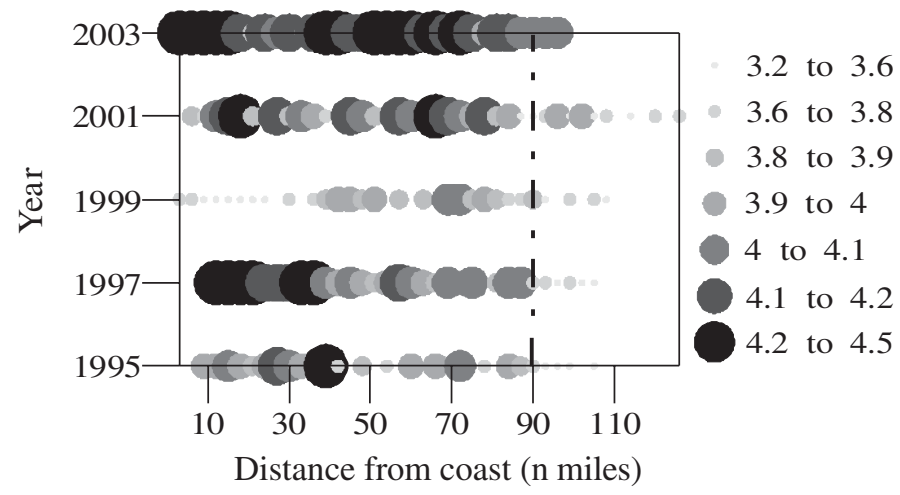

Fig. 4. Spatial distribution of the total copepod biomass ( $\mu \mathrm{g} \mathrm{C}$ $\mathrm{m}^{-3}$; logarithmic scale). Location of the shelf-break (90 $\mathrm{n}$ miles from the coast) is shown by a vertical dot-dashed line

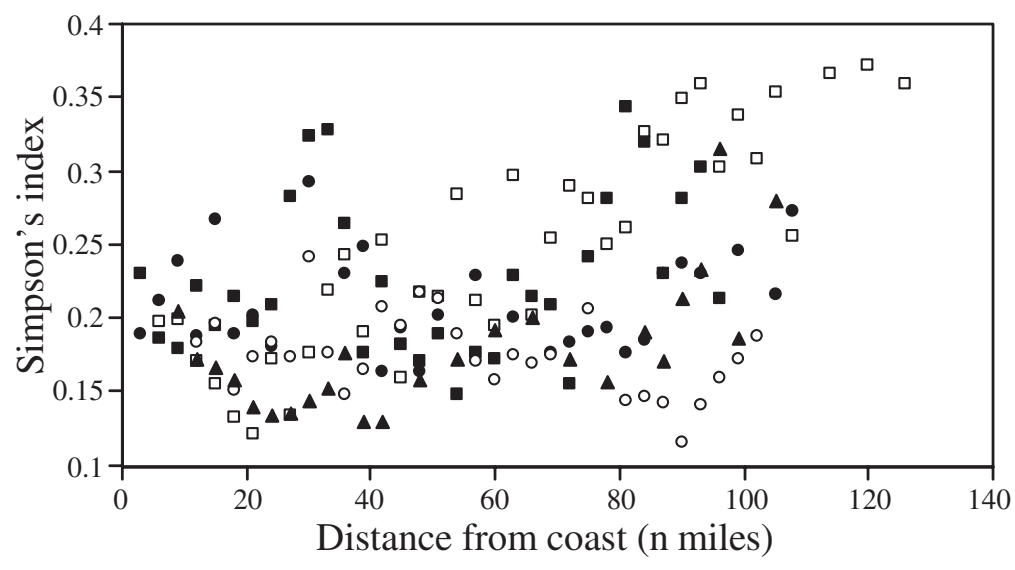

Fig. 5. Simpson's diversity index $(S)$ values for the copepod community along

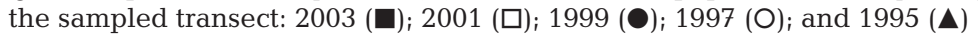

shelf-break up to $3000 \mathrm{~m}$ depth and always above $125 \mathrm{~m}, 70 \mathrm{n}$ miles from the coast). The average zooplankton density at Group ST-A1 and ST-A2 stations is inversely related to the river flow (Fig. 10).

The dendogram of zooplankton taxa identifies 2 large clusters (SP-A and SP-B), further subdivided into 3 and 2 assemblages, respectively (Fig. 11). Cluster SP-A1 is composed of characteristic nearshore taxa or species associated to the river plumes such as cirripedia nauplii (Fig. 12a), polychaeta larvae, echinodermata larvae, gastropod and bivalve veligers, the cladoceran Evadne nordmanni, and the harpacticoid copepod Euterpina acutifrons. Cluster SP-A2 includes groups with a wellknown preference for neritic habitats (with density peaking in the coastal zone) but that are able to succeed in deeper waters such as and the copepods Acartia clausi, Oncaea spp. (Fig. 12b), Temora longicornis, Pseudocalanus elongatus, and the appendicularian Oikopleura spp. Cluster SP-A3 is made up of groups that are abundant along the entire transect, comprising, except at the river plume stations, the bulk of the zooplankton abundance. The taxa grouped in Cluster SPA3 (Oithona similis [Fig. 12c], Paracalanus parvus, P-Calanus category, Centropages spp. and Corycaeus spp.) follow a bimodal distribution pattern, with the largest peak in the coastal-neritic zone and a second one over the shelf-break. Cluster SP-B1 groups taxa that have their centre of distribution in the outer-shelf and/or shelf-break zones such as Calanoides carinatus, Calanus helgolandicus (Fig. 12d), Clausocalanus spp., Ctenocalanus vanus, Oithona plumifera, Euphausiacea and the jellyfish Solmundella bitentaculata among others. Cluster SP-B2 draws together the strictly oceanic taxa that hardly cross the shelf-break front, including Calocalanus spp., Mesocalanus tenuicornis (Fig. 12e), Candacia spp., Euchaeta spp., Microsetella spp. and the appendicularian genus Fritillaria.

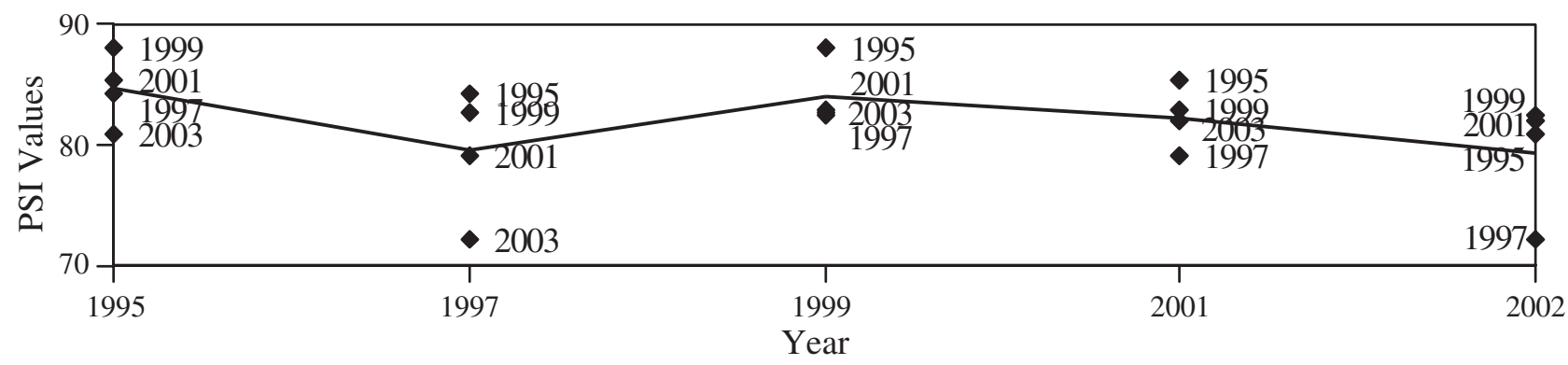

Fig. 6. Temporal percent similarity index (PSI) for the copepod community: PSI values are calculated using the percentages of abundance for each copepod species in each year's transsect pooling all stations 


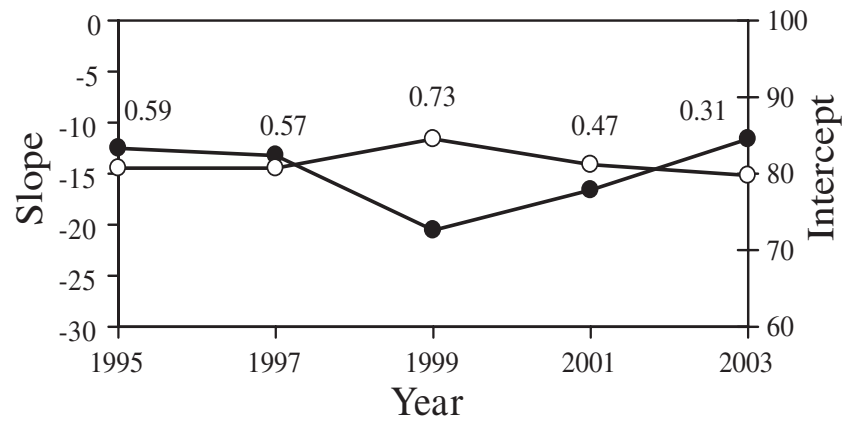

Fig. 7. Spatial PSI for the copepod community: $\mathrm{r}^{2}$ (values within the graph), slope (left axis; $\bullet$ ) and intercept (right axis; O) values for each year's linear regression are shown

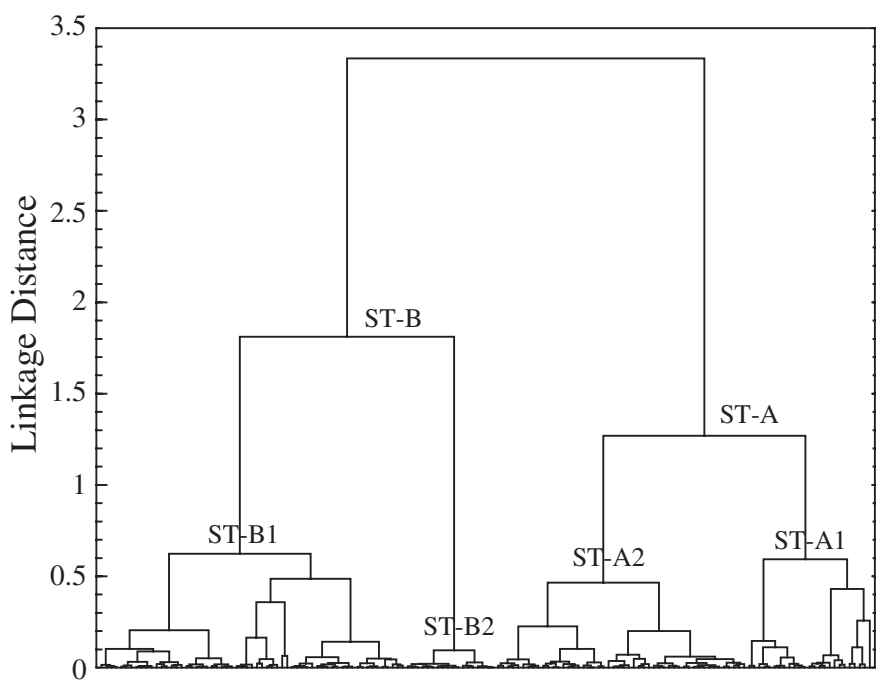

Fig. 8. Station clusters. Squared Euclidean Ward's Method Cluster applied to arc-sine (taxa density/total zooplankton density) transformed data. Groups ST-A and ST-B are further divided into 2 subgroups: ST-A1, ST-A2 and ST-B1, ST-B2, respectively

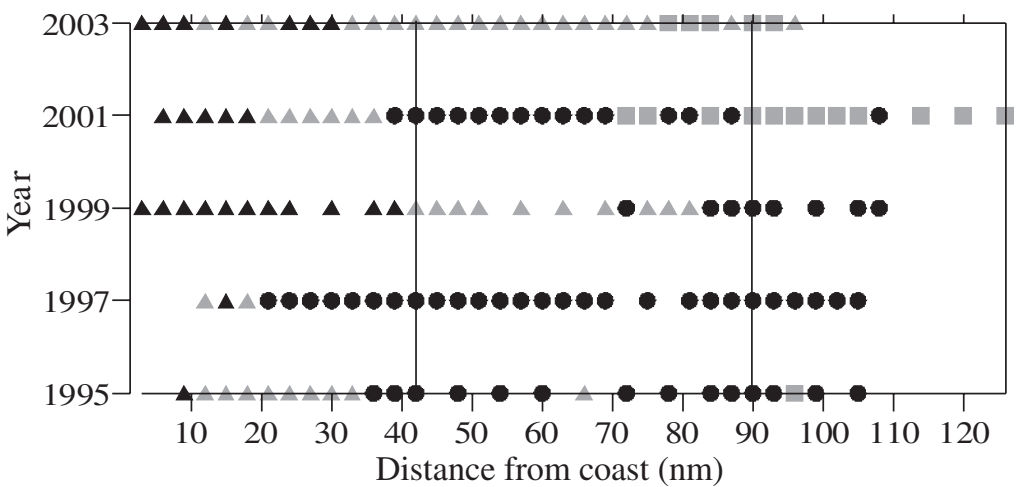

Fig. 9. Spatial distribution of different station subgroups (ST-A1, $\boldsymbol{\Delta}_{;}$ST-A2, $\triangle_{i}$ ST-B1, $;$ and ST-B2, 口). Locations of the $100 \mathrm{~m}$ isobath (42 $\mathrm{n}$ miles) and shelf-break (90 $\mathrm{n}$ miles) are shown by vertical lines

\section{Sampling resolution test}

An example of the zooplankton distributions obtained by decreasing spatial sampling resolution compared to the lowest sampling resolution ( $3 \mathrm{n}$ miles) is presented in Fig. 13a.

Fig. 13b groups chi-square values for the 5 years, showing an important temporal variability. In 1995 and 1999, deviations from the expected distribution are small whatever the spatial sampling resolution. However, in 1997, 2001 and 2003, a sigmoid trend is observed with a steep increase in the $\chi^{2}$ value when distance between stations is longer than $12 \mathrm{n}$ miles.

\section{DISCUSSION}

The effect of mesoscale structures across shelf transects is often disguised by coastal oceanic gradients due to low sampling resolution. The high resolution of our sampling design (every $3 \mathrm{n}$ miles) minimizes this problem and gives a reasonable picture of the changes in the community structure as shown by the smooth increase in PSI with distance between stations and the similarity between contiguous stations. Analysis of our data indicates that in this area a minimum resolution of $12 \mathrm{n}$ miles is necessary in order to obtain a realistic pattern of the mesozooplankton distribution.

In our transect, the most relevant structures that could affect the distribution of zooplankton are: (1) a permanent river plume in the shallowest part of the transect that normally extends over $22 \mathrm{n}$ miles from the coast (OSPAR Commission 2000), although the extension over the shelf depends on the precipitations and prevalent winds (Hermida et al. 1998, Lazure \& Jegou 1998), reaching even the shelf break (Herbland et al. 1998); (2) occasional upwellings depending on wind regime (Castaing \& Lagardre 1983, Jegou \& Lazure 1995); (3) a wide shelf zone between the shelf-break and the plume influenced by currents basically determined by the dominant winds (Koutsikopoulous \& Le Cann 1996); and (4) a shelf-break zone over the steep shelf slope where the oceanic-deep water ecosystem meets the shelf-neritic one. Consequently, 2 permanent frontal features can be expected: (1) between the low salinity river plume and the adjacent shelf; and (2) a shelf-break front between the oceanic zone and the shelf close to the slope. The Gironde river plume is a well-studied structure whose physical and biological properties agree well with those of the classical estuarine frontal systems (e.g. Le Fevre 1986, Grimes \& Kingsford 1996): 


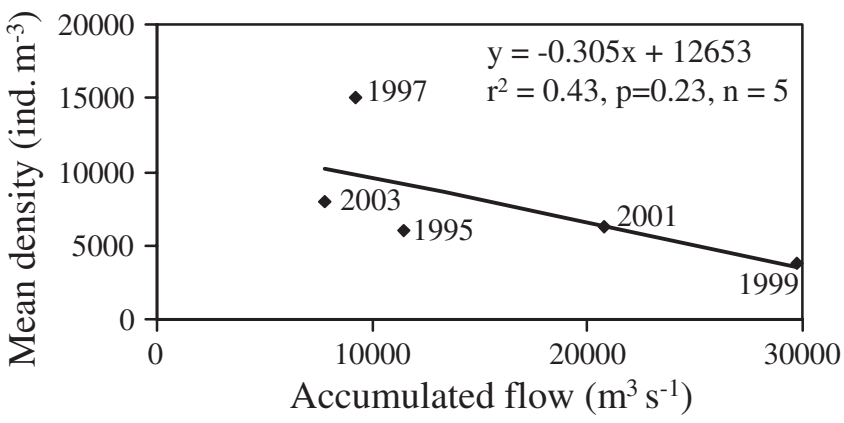

Fig. 10. Linear regression of Gironde river flow (15 d accumulated flow in $\mathrm{m}^{3} \mathrm{~s}^{-1} ; \mathrm{X}$-axis) against zooplankton mean densities (ind. $\mathrm{m}^{-3} ; y$-axis) at Group ST-A stations

plume magnitude and extension depend basically on river run-off and advection while enhanced biological production is promoted due to the continuous income of nutrients via continental drainage (Bergeron \& Herbland 2001); the frontal zone between plume and adjacent waters is characterized by strong physical and biological processes (Grimes \& Kingsford 1996).

The shelf-break zone is a less well understood structure and deserves more attention. The oscillations of temperature isoclines that extend both sides of the shelfbreak with declining amplitude as distance from the shelf-break increases (Fig. 2a-e) match the thermal signal of internal waves (Le Fevre 1986). In a stratified fluid, internal waves are the manifestation of the internal tide that results from the interaction between barotropic tide and large topographic features such as continental slopes (Baines 1982); in general, in a stratified water

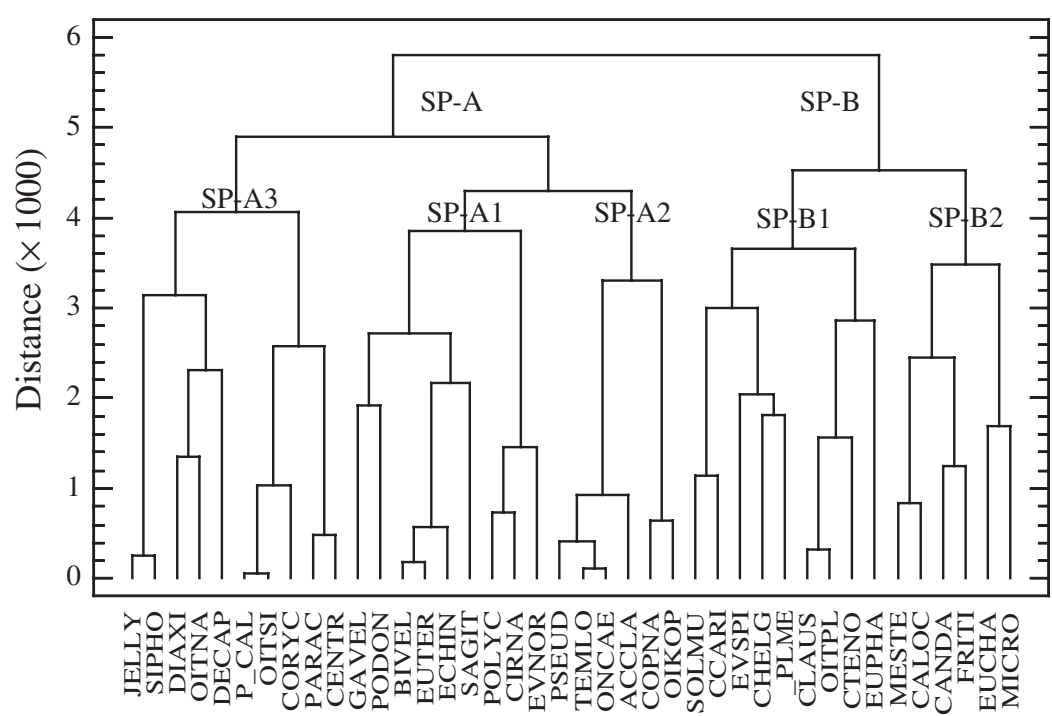

Fig. 11. Species clusters (Code column in Table 1). Two large clusters (Clusters SP-A and SP-B) are further subdivided into 3 (SP-A1, SP-A2, SP-A3) and 2 (SP-B1, SP-B2) assemblages, respectively. Squared Euclidean Ward's Method Cluster applied to $\log _{10}$ (zooplankton species density +1 ) transformed data using only taxa that conform more than $0.1 \%$ of the zooplankton community density column such as the one found in spring, wave energy is produced near the shelf-break region and propagates with decreasing amplitude (Pingree et al. 1983) in both shoreward and seaward directions (Baines 1982). The input of inorganic nutrients from deeper layers into the euphotic zone by vertical mixing due to internal waves has been observed, in both the Celtic Sea and North Biscay shelf-break, and results in enhanced phytoplankton growth in the thermocline (Pingree \& Mardell 1981, Holligan et al. 1985, Pingree et al. 1986). The 2 main centres of zooplankton abundance that we found along our transect during the spring stratification period are likely to be connected to the supply of nutrients (and enhanced primary production) due to internal wave generation over the shelf-break and to the discharge of nutrients from the Gironde estuary.

Strong contrasts in terms of population structure are usually found in frontal boundaries (Labat et al. 2002). The highest variability in $S$ values associated to both frontal structures allows them to be considered as ecological boundaries between contrasting ecosystems (Le Fevre 1986). Results from analyses of stations and species clusters clearly emphasize the main role of plume and shelf-break fronts in determining, both quantitatively and qualitatively, the different zooplankton assemblages along the cross-shelf transect; 2 productivity 'hot spots' are found to be related to the front-influenced zones, comprising a bimodal distribution of zooplankton densities and determining the distribution centres of zooplankton communities that can be summarized as follows (synthesis in Fig. 14): (1) a river plume influenced zone, which can be assigned to communities at Group ST-A stations whose densities respond to river run-off magnitudes and are related to the species grouped in Cluster SP-A (neritic species); (2) a shelf-break frontal zone in the outer shelf where chl a peaks, representing the centre of distribution for species in Cluster SP-B1 (shelf species), a secondary peak for species in Cluster SP-A3 and the penetration limit for Cluster SP-B2 species (oceanic species); (3) the shelf portion between both frontal structures dominated by Cluster SP-A3 species, showing much lower abundances than the adjacent frontal areas; and (4) an oceanic zone (Group ST-B2 stations), with the overall lowest densities characterized by Cluster SP-B2 species. Exceptional meteorological events can disrupt the general pattern described above by changing the main driving ecological properties. Apparently, in 1997, an upwelling event seems to have taken place close to the coast (20 to $30 \mathrm{n}$ miles from the coast; Fig. 2b), restricting the extension of zooplankton plume 
a)

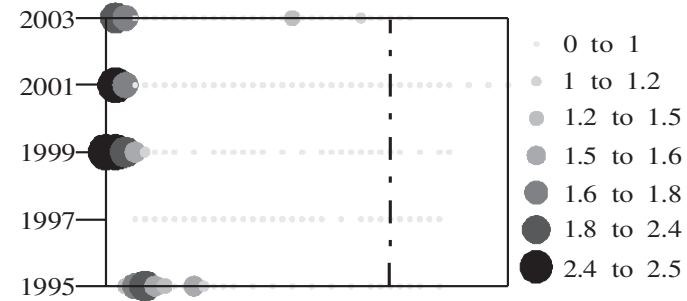

c)

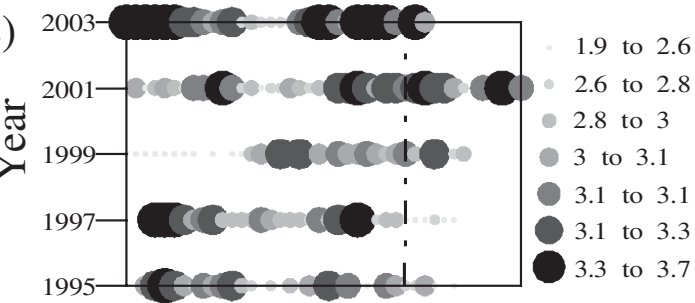

e)

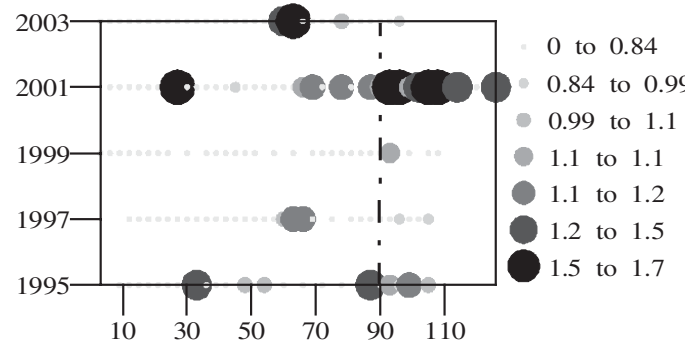

Distance from coast (n miles)

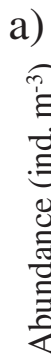

a)

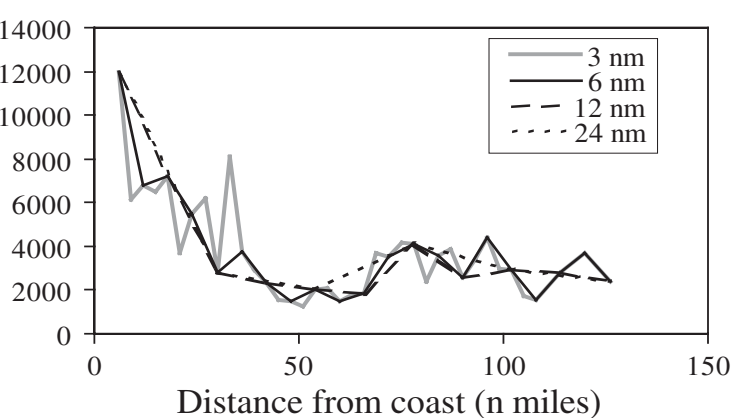

b)

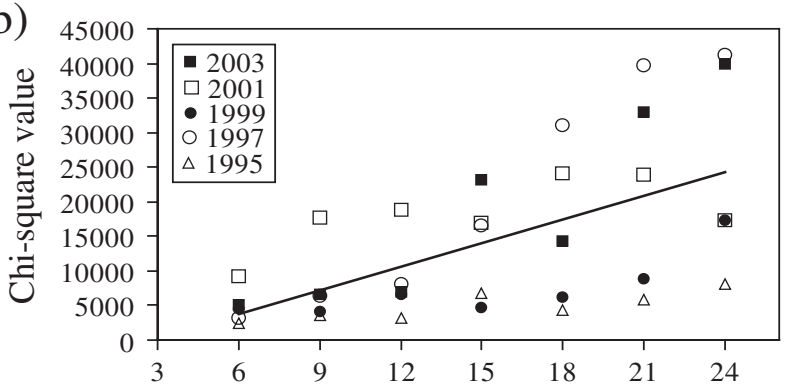

Distance between sampled stations (n miles)

Fig. 13. Sampling resolution test: (a) zooplankton abundance (ind. $\mathrm{m}^{-3}$ ) distributions for the 2001 transect with decreasing sampling resolution; (b) chi-square values for the $5 \mathrm{yr}$ comparison between expected and observed total zooplankton abundance distributions with increasing distance between stations sampled (the linear regression trend is superimposed in the graph; $y=1145 x-3186.7 ; r^{2}=0.37$ ) b)

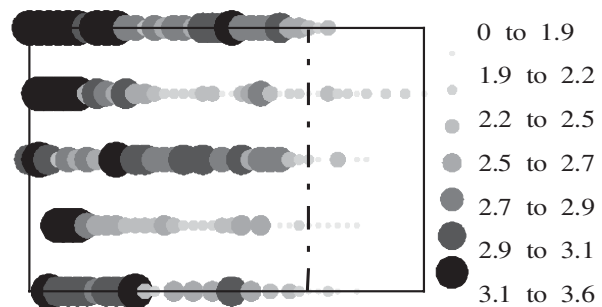

d)

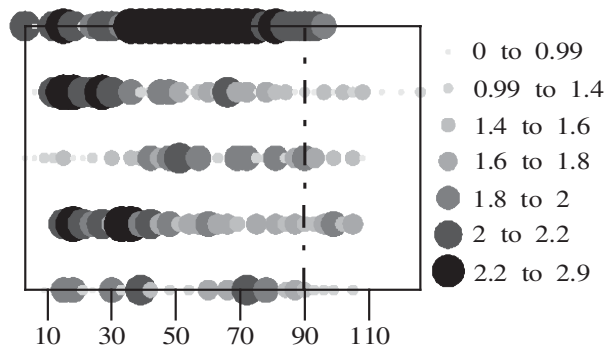

Distance from coast (n miles)

Fig. 12. Spatial distributions of selected taxon densities (ind. $\mathrm{m}^{-3}$; logarithmic scale): (a) cirripedia nauplii; (b) Oncaea spp.; (c) Oithona similis; (d) Calanus helgolandicus; and (e) Mesocalanus tenuicornis. Location of the shelf-break ( $90 \mathrm{n}$ miles from the coast) is shown

communities over the shelf (Groups ST-A1 and ST-A2 in Fig. 9) and promoting a peak of Calanus helgolandicus in the upwelled waters (Fig. 12d); peaks in abundances associated with upwelled water masses is a pattern currently observed in Chilean shelf waters for the congeneric C. chilensis (Giraldo et al. 2002). In 1999, the exceptional outflow from the Gironde river in the days preceding the survey could explain the lack of the neritic zooplankton peak, as communities related to the Gironde plume would have be washed away. Decreases in zooplankton abundance after storms involving enhanced precipitation have already been described for the nearby Arcachon Bay (Vincent et al. 2002).

Copepod abundance follows a bimodal distribution clearly related to the position and characteristics of the frontal structures and to the associated chlorophyll pattern. However, when taking into account biomasses, the transect presents a more homogenous structure due to the increasing role of $>2 \mathrm{~mm}$ copepods, particularly the relatively abundant Calanus helgolandicus, in the mid-outer shelf. Neritic species of copepods are commonly smaller in body size compared with offshore species (Mauchline 1998); however, this does not explain the significant biomass due to large copepods in the mid-shelf. Total copepod biomass in midshelf waters were comparable to those calculated for the associated waters in the adjacent frontal structures, suggesting that ecological relationships more complex 


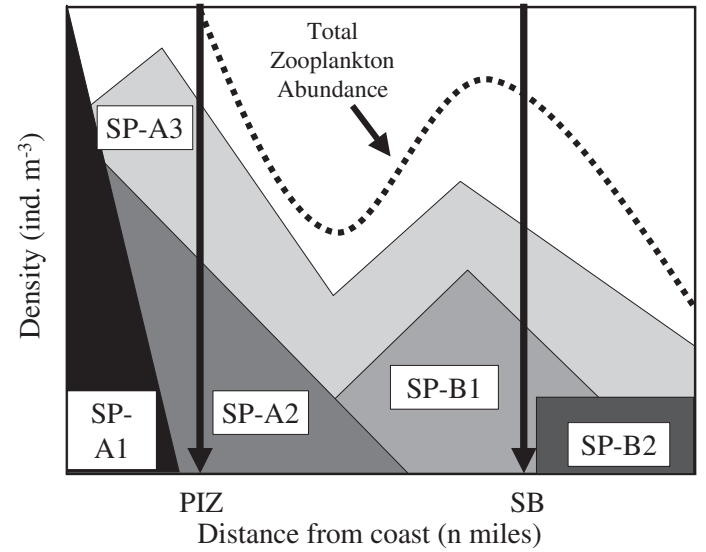

Fig. 14. Synthetic diagram describing zooplankton communities in relation to the river plume influenced zone (PIZ) and the shelf-break front position (SB). Dotted line integrates total zooplankton abundance while SP-A1, SP-A2, SP-A3, SP-B1 and SP-B2 correspond to species cluster's subgroups

than increased primary production-increased zooplankton biomass could be involved.

These distributions could be related to habitat preference (food, retention, depth) or predation avoidance. As an example, a depth preference for mid-outer shelf habitats has been described for the population of Calanus sinicus in Japanese shelf waters due to requirements for reproduction success (Uye 2000).

In contrast, the bimodal distribution of zooplankton peak densities and the differential repartition of the copepods along the transect, with peaks of density in the plume and shelf-break, fit well with the described spatial distribution for the zooplanktivorous Biscayan anchovy Engraulis encrasicolus: larger individuals (Year Class 2) concentrate along the shelf-break whereas smaller ones (Year Class 1) are abundant in plume waters (Motos et al. 1996). Therefore, regardless of the reduced primary production, the mid-shelf waters could represent a gap in predatory pressure, allowing the development of the Calanus helgolandicus population. Strong relationships between anchovy feeding and zooplankton composition have already been suggested for the Bay of Biscay (Plounevez \& Champalbert 1999). However, the population of $C$. helgolandicus could be the one that exerts a high predation pressure on the early stages of zooplankters (e.g. Corner et al. 1976, Landry 1981, Kang et al. 2000, Lopez-Urrutia et al. 2003) in the mid-shelf. This would result in the bimodal distribution of the abundance of the small species with a gap in the mid-shelf.

The determination of the mechanisms resulting in the described biomass distribution will require improved knowledge of the transport from both frontal areas to the mid-shelf and retention in that area, as well as a better understanding of the predation pressure from vertebrate predators and between zooplankters.

\section{CONCLUSIONS}

In the present study, the observed distinct zooplankton peak abundances and species assemblages appear to be related to the position and run-off of the river plume and to frontal structures associated with the shelf-break. However, copepod biomass seems to have a more homogenous distribution than abundance, suggesting that other factors apart from primary production enhancement are involved in the determination of the secondary production pattern along the transect.

Acknowledgements. We are grateful to the crew of the RV 'Investigador' and the onboard scientists and analysts for their support during sampling. Thanks are due to E. San Martin and R. P. Harris for revising the text, to M. Santos for providing $\mathrm{Nv}$-shuttle profile and to $\mathrm{V}$. Valencia and the harbour authority of Bordeaux for the Gironde river flow data. SeaWiFS image acquired and processed by the remote sensing unit of AZTI Foundation. A.A.'s work was supported by a doctoral fellowship of the Education, Universities and Research Department of the Basque Country Government, Spain. X.I. is partially supported by a Ramon Y Cajal grant from the Spanish Ministry of Research. We would also like to thank the 3 anonymous reviewers for their useful comments.

\section{LITERATURE CITED}

Baines PG (1982) On internal tide generation models. DeepSea Res 29(3A):307-338

Bamstedt U (1986) Chemical composition and energy content. In: Corner EDS, O'Hara SCM (eds) The biological chemistry of marine copepods. Clarendon Press, Oxford, p 1-58

Beaudouin J (1971) Données écologiques sur quelques groupes planctoniques indicateurs dans le Golfe de Gascogne. Rev Trav Inst Pech Marit 35(4):375-414

Beaudouin J (1975) Copepodes du plateau continental du Golfe de Gascogne en 1971 et 1972. Rev Trav Inst Pech Marit 39(2):121-169

Bergeron JP, Herbland A (2001) Pyruvate kinase activity as index of carbohydrate assimilation by mesozooplankton: an early field implementation in the Bay of Biscay, NE Atlantic. J Plankton Res 23(2):157-163

Castaing P, Lagardre F (1983) Variations saisonnieres de la temperature et la salinité des eaux du plateau continental aux abords de la Gironde. Bull Inst Geol Bassin Aquitaine 33:61-69

Chiba S, Ishimaru T, Hosie GW, Fukuchi M (2001) Spatiotemporal variability of zooplankton community structure off east Antarctica (90 to $160^{\circ}$ E). Mar Ecol Prog Ser 216: 95-108

Corner EDS, Head RN, Kilvington CC, Pennycuick L (1976) On the nutrition and metabolism of zooplankton. X. Quantitative aspects of Calanus helgolandicus feeding as a carnivore. J Mar Biol Assoc UK 56:345-358

d'Élbee J, Castel J (1991) Zooplankton from the continental shelf of the southern Bay of Biscay exchange with Arcachon Basin, France. Ann Inst Oceanogr Paris 67(1): $35-48$

Errhif A, Razouls C, Mayzaud P (1997) Composition and community structure of pelagic copepods in the Indian sector of the Antarctic Ocean during the end of the austral summer. Polar Biol 17:418-430 
Farran GP (1926) Biscayan plankton collected during a cruise of H.M.S. 'Research', 1900. Part XIV. The Copepoda. Linn J Zool Vol XXXVI:219-310

Fernandez E, Cabal J, Acuña JL, Bode A, Botas A, GarcíaSoto C (1993) Plankton distribution across a slope currentinduced front in the southern Bay of Biscay. J Plankton Res 15(6):619-641

Franks PJS (1992a) Phytoplankton blooms at fronts-patterns, scales, and physical forcing mechanisms. Rev Aquat Sci 6:121-137

Franks PJS (1992b) Sink or swim: accumulation of biomass at fronts. Mar Ecol Prog Ser 82:1-12

Gaudy R, Boucher J (1983) Relation between respiration, excretion (ammonia and inorganic phosphorus) and activity of amylase and trypsin in different species of pelagic copepods from the Indian Ocean equatorial area. Mar Biol 75:37-45

Giraldo A, Escribano R, Marin V (2002) Spatial distribution of Calanus chilensis off Mejillones Peninsula (northern Chile): ecological consequences upon coastal upwelling. Mar Ecol Prog Ser 230:225-234

Grimes CB, Kingsford MJ (1996) How do riverine plumes of different sizes influence fish larvae: do they enhance recruitment? Mar Freshw Res 47:191-208

Herbland A, Delmas D, Laborde P, Sautour B, Artigas F (1998) Phytoplankton spring bloom of the Gironde plume waters in the Bay of Biscay: early phosphorus limitation and foodweb consequences. Oceanol Acta 21(2):279-291

Hermida J, Lazure P, Froidefond J, Jegou A (1998) La dispersion des apports de la Gironde sur le plateau continental: données in situ, satellitales et numeriques. Oceanol Acta 21(2):209-221

Holligan PM, Pingree RD, Mardell GT (1985) Oceanic solitons, nutrient pulses and phytoplankton growth. Nature 314:348-350

Jegou AM, Lazure P (1995) Quelques aspects de la circulation sur le plateau atlantique. In: Cendrero O, Olaso I (eds) Actas del IV Coloquio Internacional sobre Oceanografía del Golfo de Vizcaya. Instituto Español de Oceanografía, Santander, p 99-106

Joyce TM (1983) Varieties of ocean fronts. In: Stern ME, Mellor FK (eds) Baroclinic instability and ocean fronts. Technical Report No. 83-41. Woods Hole Oceanographic Institution, Woods Hole, MA

Kang HK, Poulet S, Lacoste A, Kang YJ (2000) A laboratory study of the effect of non-phytoplankton diets on the reproduction of Calanus helgolandicus. J Plankton Res 22: 2171-2179

Koutsikopoulous C, Le Cann B (1996) Physical processes and hydrological structures related to the Bay of Biscay anchovy. Sci Mar 60(Suppl 2):9-19

Labat JP, Mayzaud P, Dallot S, Errhif A, Razouls S, Sabini S (2002) Mesoscale distribution of zooplankton in the SubAntartic Frontal System in the Indian part of the Southern Ocean: a comparison between optical plankton counter and net sampling. Deep-Sea Res I 49:735-749

Landry MR (1981) Switching between herbivory and carnivory by the planktonic marine copepod Calanus pacificus. Mar Biol 65:77-82

Lazure P, Jegou A (1998) 3D modelling of seasonal evolution of Loire and Gironde plumes on Biscay Bay continental shelf. Oceanol Acta 21(2):165-177

Le Fevre J (1986) Aspects of the biology of frontal systems. Adv Mar Biol 23:163-299

Lopez-Urrutia A, Harris RP, Smith T (2003) Predation by calanoid copepods on the appendicularian Oikopleura dioica. Limnol Oceanogr 49:303-307
Mauchline J (1998) The biology of calanoid copepods. Adv Mar Biol 33:1-710

Motos L, Uriarte A, Valencia V (1996) The spawning environment of the Bay of Biscay anchovy (Engraulis encrasicolus L.). Sci Mar 60(Suppl 2):117-140

Munk P, Hansen BW, Nielsen TG, Thomsen HA (2003) Changes in plankton and fish larvae communities across hydrographic fronts off West Greenland. J Plankton Res 25(7):815-830

OSPAR Commission (2000) Quality Status Report 2000: Region IV-Bay of Biscay and Iberian Coast. OSPAR Commission, London

Pakhomov EA, Perissinotto R, McQuaid CD, Froneman PW (2000) Zooplankton structure and grazing in the Atlantic sector of the Southern Ocean in late austral summer 1993. Deep-Sea Res I 47:1663-1686

Pielou EC (1984) The interpretation of ecological data. John Wiley, New York

Pinca S, Dallot S (1995) Meso- and macrozooplankton composition patterns related to hydrodynamic structures in the Ligurian Sea (Trophos-2 experiment, April-June 1986). Mar Ecol Prog Ser 126:49-65

Pinca S, Dallot S (1997) Zooplankton community structure in the Western Mediterranean Sea related to mesoscale hydrodynamics. Hydrobiologia 356:127-142

Pingree RD, Mardell GT (1981) Slope turbulence, internal waves and phytoplankton growth at the Celtic Sea shelfbreak. Phil Trans R Soc Lond A 302:663-682

Pingree RD, Griffiths DK, Mardell GT (1983) The structure of the internal tide at the Celtic Sea shelf break. J Mar Biol Assoc UK 64:99-113

Pingree RD, Mardell GT, New AL (1986) Propagation of internal tides from the upper slopes of the Bay of Biscay. Nature 321:154-158

Plounevez S, Champalbert G (1999) Feeding behaviour and trophic environment of Engraulis encrasicolus (L.) in the Bay of Biscay. Estuar Coast Shelf Sci 49:177-191

Rebstock GA (2001) Long-term stability of species composition in calanoid copepods off Southern California. Mar Ecol Prog Ser 215:213-224

Sautour B, Castel J (1993) Distribution of zooplankton populations in Marennes-Oleron Bay (France), structure and grazing impact of copepod communities. Oceanol Acta 16(3):279-290

Simpson EH (1949) Measurement of diversity. Nature 163: 688

Smith PE, Flerx W, Hewitt RH (1985) The CalCOFI Vertical Egg Tow (CalVET) Net. In: Lasker R (ed) An egg production method for estimating spawning biomass of pelagic fish: application to the northern anchovy, Engraulis mordax. NOAA Technical Report NMFS 36. US Department of Commerce, Washington, DC, p 27-32

Thiriot A (1976) Zooplancton et micronecton du Golfe de Gascogne. Publ CNEXO, Result Camp Mer 9:63-126

Uye S (2000) Why does Calanus sinicus prosper in the shelf ecosystem of the Northwest Pacific Ocean? ICES J Mar Sci 57:1850-1855

Vincent D, Luczak C, Sautour B (2002) Effects of a brief climatic event on zooplankton community structure and distribution in Arcachon Bay (France). J Mar Biol Assoc UK $82: 21-30$

Ward JH (1963) Hierarchical groupings to optimize an objective function. J Am Stat Assoc 58:236-244

Whittaker RH, Fairbanks CW (1958) A study of plankton copepod communities in the Columbia Basin, southeastern Washington. Ecology 39:46-65 